ARTICLE

DOI: $10.1057 /$ s41599-017-0059-3

\title{
Meritocracy and inequality: moral considerations
}

\author{
Theodros Assefa Teklu ${ }^{1}$
}

\begin{abstract}
This study investigates where religion stands in relation to economic life, characterised by meritocracy. To this end, first, the deeper logic of economic merit-retribution-which captures humans, as an ideology of everyday life-will be explicated through a cursory review of the metaphysical and religious grounding of economic life. Here, the paper discusses both the religious legitimation and critique of meritocracy by generating theological resources from the books of Job and Qohelet. The paper then draws on the historical archives and cultural memories of Ethiopians to illustrate how and why religion should be considered important for a deeper understanding of inequality and poverty. Of particular interest in this context are the oral poetic expressions of ordinary people suffering the consequences of drought and famine in Ethiopia. Such voices-usually passed unheard by authorities, whether governmental or non-governmental agents-are not only illustrative of the way the logic of merit/retribution is implicated in metaphysical and religious worldviews in Ethiopia (the metaphysics of fate/idil), but also demonstrate a challenge to the religious, socio-economic, and political status quo. Finally, the paper suggests a number of moral considerations on meritocracy vis-à-vis inequality and poverty, which will contribute towards correcting flawed conceptions of economic poverty and development.
\end{abstract}

\footnotetext{
${ }^{1}$ Ethiopian Graduate School of Theology, Addis Ababa, Ethiopia. Correspondence and requests for materials should be addressed to T.A.T. (email: theodrosa2013@gmail.com)
} 


\section{Some premises}

erit is the great paradox of the economic cult of our time" (Bruni, 2017). The applicability of the principle of merit has always been a contentious issue. Central to the debate-between liberals (proponents) and egalitarians (critics) of meritocracy-is the notion of desert, which entails that people should get only what they deserve. Deservingness, or reward, could be dependent on one or more of the following: contribution, effort, and compensation-requiring proportionality of reward and cost (Miller, 1976, p 103). The structure of desert takes into account the relationship between the subject (S), the mode of treatment $(\mathrm{M})$, and the desert base or the reason for the desert (B). The following formula expresses the relationship between the three elements: $S$ deserves $M$ in virtue of B. ${ }^{1}$ Two preconditions should be in place in order for the principle of desert to make sense. First, there should be equality of opportunity, such that everyone has equal access to compete for scarce goods/resources. Second, the condition of fairness has to be fulfilled for it would not be fair "if A were to receive X for Y but B Z for the same Y" (Schweiger, 2014, p 51).

Nonetheless, meritocracy, which implies a system of rewards (merit or demerit, based on desert), raises serious questions of justice (Miller, 1976, p 103-121). Under idyllic conditions, people could be rewarded based on their efforts or contribution, but in actual situations, there are always people whose rewards are not commensurate with their efforts or contributions. In addition, no one starts equal, and it must not be forgotten that there are people involuntarily without the means or option to contribute (see Schweiger, 2014, p 37-61).

An aspect of the paradox of meritocracy lies in the discrepancy between its ideal promise and its actual, concrete delivery. In other words, meritocracy, which claims distribution of resources based on individual merit, is not genuine-or, it is a myth (in the pejorative sense of the word) (McNamee and Miller, 2004). Merit and non-merit factors such as inheritance, luck, and all sorts of cultural and social advantages are often mixed up in the myth. In concrete terms, what matters at the end of the day is not only talent and hard work, which make individuals competitive in meritocratic systems. This implies that a just or pure meritocracy is an impossibility. Instead, because of this mélange of merit and non-merit factors, what we have is a kind of lottery-like randomness, which I opt to call (oxymoronically) aleatoric or dicelike meritocracy. In aleatoric meritocracy, life is subjected to the randomness of chance in which the fittest survives (social Darwinism)-sometimes, through mechanisms of nepotism and oligarchy. From an egalitarian standpoint, one could raise appropriate questions such as-"How could meritocracy be fair when the starting points of life are not levelled for everyone by redressing initial inequalities? How does the individual who starts of at the lowest rung thrive? Are all unemployed people censurable?"

John Rawls, who attempts to engage the debate by rejecting the notion of desert, accentuates the need for a "public conception of justice" with "the tendency to equality" in order to make use of scarce resources (Gaus, p 201; Rawls, [1999] 1971, p 86-92). Society is unfair if it preferentially privileges those winners of the "natural lottery" by accident of birth over those who are not endowed with natural talents and social advantage (Gaus, p 202; Rawls, p 88-89; Gaus and D'Agostino 2013, p 722-735). He thus rejects the notion of desert. Instead, he proposes the strategy of "maximin" whereby the benefits to those at a disadvantage are maximised (Rawls, p 86-87). This difference principle dovetails with the principle of redress that aims at correcting past injustice, which would give everyone equality of opportunity. Nonetheless, egalitarians still critique Rawls's theory as inadequate for a comprehensive egalitarian vision because of its individualistic and competitive understanding of society. Although he claims that his argument, based on equality of opportunities, does not necessarily indicate the affirmation of meritocracy, Rawls does not escape the charge.

The cursory rehearsal of the theoretical trajectories I have attempted here is intended to establish the context for my own approach to the problem. My contention is that meritocracywhether it is officially adopted as a policy or not-remains a powerful force, not so much for its conceptual cogency as for its promises and lures hooking into people's belief systems. Arguably, at a deeper existential level, there seems to be a human desire to establish an organic or causal link between the efforts we exert and the rewards we receive. This entails considering meritocracy as a regime of subjectivity that disciplines people's desire -capturing and shaping their imaginations and actions.

Having made the proposal that meritocracy could be considered a regime of subjectivity, it would then be natural to explore also the significance of religion in understanding economic relations characterised by meritocracy. This will allow us to enquire into the location of religion in relation to inequality and poverty. To this end, I will start with a brief review of the economic de/merit logic to examine both the religious legitimation and critique of meritocracy to argue that meritocracy prevails not because of its conceptual cogency, but rather because it appeals the subjectivities of people in a quasi-religious manner. In this section, I will look at selected Christian texts dealing with merit, as an example of how religion could be caught in the tension between merit and grace. Here, I also wish to generate theological resources from Job and Qohelet that problematise the causal connection between merit and reward. In doing this I hope to indicate not only the manner in which religion could be instrumentalised to legitimise meritocracy but to also demonstrate its capacity to critique and resist.

I will then, move on to look at an example from the Ethiopian context to broaden the horizon of the discussion. To this end, I will draw on the historical archives and cultural memories of Ethiopians-focusing on the oral poetic expressions of the effects of drought on ordinary people- to illustrate the extent to which religion is an important factor in achieving a deeper understanding of inequality and poverty. Such voices-which usually pass unheard by authorities, whether governmental or nongovernmental agents-are not only illustrative of the way the logic of merit/retribution is explicated in their metaphysical and religious worldviews (the metaphysics of fate/idil), but also demonstrate a challenge to the religious, socio-economic, and political status quo. Finally, I will conclude the discussion by suggesting a number of moral considerations on meritocracy visà-vis inequality and poverty, which will contribute towards correcting flawed conceptions of economic poverty and development.

\section{Religion and the de/merit economic logic}

In this section, I will discuss the relation between meritocracy and religion. I will examine the following two questions concerning the manner in which religion legitimises meritocracy and concerning the moral critique, it poses. Allow me to start by rehearsing theoretical trajectories that are pertinent for examining the relation between religion and economy in general.

Meritocratic religion?. In The Protestant Ethic and the Spirit of Capitalism, Max Weber ([1930] 2005, pp 53-125) promotes the argument that Protestantism fostered a culture that interpreted worldly economic success as a sign of election and salvation, suggesting that meritocracy develops out of a religious worldview. According to Weber's analysis, material wealth (money) is an 
indicator of grace. This link between grace and money can be presented in a two-way relationship where grace means money and money means grace. If we follow Weber's argument, we find that Calvin's doctrine of predestination contributed to the transformation of attitudes, particularly the shift from otherworldly ascetic disposition to an inner-worldly one. In addition, such a move resulted in hard work to prove election through the gain of worldly wealth. Moreover, this contributed to the development of rational calculation/manipulation of social and economic resources towards capitalistic ends (rational capitalism). In general, Protestant Christianity-as a meritocratic religionfostered a culture favourable for the development of capitalistic economy.

Applying a variant of Weber's analysis to the contemporary situation may require empirical considerations in particular local contexts. However, given the globalisation of capital and the liberalisation of the market across the world, it would not be entirely inappropriate to think of meritocratic culture and the spirit of capitalism as a global phenomenon. If that is the case, even contemporary expressions of religion, including various Christian traditions (e.g., pentecostal, neo-pentecostal movements) and expressions of African Traditional Religions variously exhibit similar trends. For a meritocratic religion to flourish at a global scale, it is not necessary for the entire world to convert or to have links with Protestant Christianity. As the famous aphorism by the philosopher Walter Benjamin captures, "Capitalism" itself "is a religion, that is to say, capitalism essentially serves to satisfy the same worries, anguish, and disquiet formerly answered by so-called religion. [...] capitalism itself developed parasitically on Christianity in the West" (Benjamin, [1986] 1921, p 102). Benjamin's articulation suggests the replacement of the old religion (Christianity) by the new (Capitalism). What is important to note here is the operative logic of meritocratic religion: it only needs favourable religious worldviews that could serve as hosts to foster its parasitic growth. Thus, what has happened in the west could also happen in the non-west in diverse ways.

According to the view proposed by Benjamin, capitalism is intimately related to our existential "worries, anguish, and disquiet". In other words, it enters our subjectivity and shapes our whole being. In this light, we can see that belief in merit plays a great role connecting people's belief system with the operative logic of economy. Belief in merit-which is both old and newresonates deeply with modern economic conceptions that enter or constitute people's subjectivity, affecting the way they conceive themselves and their world. In this regard, I agree with the Italian economist Luigino Bruni (2017), who argues that meritocracy involves a "symbolic technology" that is of a double nature, fostering an interpretation of meritability and organisational rationality (cf. Louis Althusser's ideology and mastery and Michel Foucault's technologies of the self; Althusser, 2008 and Luther et al., 1988). On the one hand, it causes the employee to consider that his/her work is recognised and well valued and that it deserves merit (meritable), while on the other hand, it causes the employer to think that he/she is fair to the employee. Of course, this is just an example and merit is not limited to employment. Thus, meritocracy captures humankind because of its strong appeal, and it proves to be a regime of subjectivity that disciplines the human subject.

In today's world, economy means a matter of survival: life and death, to be and not to be. "A new world has arisen", writes Sergius Bulgakov, "a new organisation of life, in which every man [sic] feels himself to be only an insignificant part of the whole, a little screw in a big machine" (Williams, 1999, p 276). Such a new world has come at the expense of the dis-embedding of older orders of life. According to Charles Taylor, one of the most prominent contemporary philosophers, (2007, p 181), the conception of economy as a self-regulating system is not natural or God-given; rather, it is a social construction whose origin extends back only to the eighteenth century. Such a conception of the economy, which was only a theory in the mind of "Adam Smith and the physiocrats", eventually extended to constitute people's imaginations and actions becoming what Taylor calls a "modern social imaginary" (2004, p 76).

A social imaginary describes "the ways people imagine their social existence, how they fit together with others, how things go on between them and their fellows, the expectations that are normally met, and the deeper normative notions and images that underlie these expectations" (Taylor, 2004, p 23). Implied in this conception are the following fundamental realities: (1) the economy should be free from any intervention because it can maintain its own equilibrium; (2) we, as economic actors, are free beings; (3) and what binds us together is our common belief in such a convention. Intricately related to our self-understanding, social imaginaries do have the capacity to constitute our subjectivities.

The purpose of alluding to these three prominent social theorists and philosophers is not to engage with or appropriate their works here but to show how they-in their own distinct idioms-furnish us with conceptual tools to understand general economy in terms of religiously informed cultural development (Weber and Benjamin) and social imaginaries (Taylor). Such conceptual trajectories (especially, the former) with historical justifications offer us an account of religion that can legitimise meritocratic belief that intimately affects and coordinates our imaginations and actions. Although this may give us a proper understanding of the mal/functions of religion, it is not immediately obvious how religion could be seen as a resistance to meritocratic beliefs. Could we speak of a religious reserve that is counter-meritocratic? It is to this fundamental question that the following discussion will address itself.

Anti-meritocratic sage philosophy/theology. The fact that meritocracy constitutes our subjectivity does not mean that we are entirely determined by it. Determinism could be "true only if our 'I' were dead" (Bulgakov, 2000, p 212) and "there could be no critique at all" if everything else "were nothing but pure utility" (Hughes, 2007, p 224). Consequently, it is possible to think of critique and resistance against meritocracy, and such resistance against meritocratic ideology could evolve out of the same religious and metaphysical repository that sanctions meritocracy.

Therefore, in generating theological resources from the biblical tradition, I do so with the intention to contest meritocracy, which could legitimately be considered as (part of) a particular (liberal) tradition (MacIntyre, 1988, p 335; Gaus, p 224-225). Here I echo Kathryn Tanner who argues that "theological ideas are always constituted by a contestatory relationship with the beliefs and practices of the wider world" (Tanner, 2005, p 1). In what follows, I will examine the paradox of merit in the Judeo-Christian biblical tradition ${ }^{2}$ particularly focusing on Job and Qohelet to articulate the contestatory relationship between theology and merit (cf. Schweizer, 1975, p 155; Tushima, 2011, p 1-11). ${ }^{3}$

In their anti-meritocratic stance, the books of Job and Qohelet are arguably without equal. Here, I will focus on some selected texts, from these books, to generate theological resources against meritocratic religion/theology. The intention here is not entirely theological though. Although they have explicit theological thought, these books-which are often referred to as wisdom literature-demonstrate the character of a sage philosophy that can be deployed to produce a critical voice that counters 
meritocracy. I will start with a text from Qohelet, which problematises merit:

Again I saw that under the sun the race is not to the swift, nor the battle to the strong, nor bread to the wise, nor riches to the intelligent, nor favor to the men of skill; but time and chance happen to them all.

For man does not know his time. Like fish which are taken in an evil net, and like birds which are caught in a snare, so the sons of men are snared at an evil time, when it suddenly falls upon them. (Ecc. 9:11-12 RSV)

In this text, Qohelet does not imply that the swift never win. Rather, he affirms that the swift cannot possess, and consequently control, the race: "It is not the loss of a race by the swiftest runner that troubles Qohelet, nor the poverty of a wise man, but rather the evidence such inequities provide of the ineffectuality of human skills and powers" (Fox, 1989, p 260-261). The cause of this ineffectuality is "time and accident". Here, what "Qohelet has in mind in this verse are unfortunate, for they deprive people of the just rewards of their talents" (Fox, 1989, p 260-261). It refers to the "time of misfortune" that befalls humans as a mishap or trap, something of a disaster that results in the individual's (premature/untimely) death (Fox, 1989, p 260-261).

What one should note is that the problem is less about the notion of merit/retribution than the answers attributed to the questions related to the recognition of merits or demerits. Qohelet accentuates the contradictory co-existence of justice and the lack of it (injustice) in society. Theodicy-the justification of God in the presence of evil-appears to occupy Qohelet's mind, but he is less interested in the solution itself than in showing the disruptive force of exceptions (crisis) that lead to the questioning of earlier conventional views of justice (Fox 1989, p 146-147).

Here, one may raise a legitimate question as to the coherence of Qohelet's philosophy: how could he affirm the co-existence of a just God and an unjust world-two seemingly contradictory propositions. Of course, this may lead us to abandon one of the propositions that may eventually lead to atheistic conclusions. In this respect, Qohelet (Fox, 1989, p 146-150) displays recognition of disruptions without necessarily abandoning belief in the justice and judgement of God, and such contradictions can also be explained in terms of "split subjectivity" in a post-modern idiom (Koosed, 2006, p 59). By split-subjectivity, I am referring not to a form of schizophrenia or bipolar condition, but to the fragmentary and sometimes incoherent sets of identity/identification that constitute the self. In Qohelet, we find reservation of the subject's freedom to resist the determinism of objective conditions. In brief, as mentioned above, total determinism is impossible-we humans cannot be determined through and through by the force of material conditions as long as we are (or, our "I" is) not dead.

In the book of Job, we find contentious and divergent views on merit and retribution. There is a strand of thought that counts earthly, temporal prosperity as merit and retribution as demerit (a view represented by Job's friends), and a view that questions the equating of worldly prosperity and wellbeing with divine merit, or providence. Nevertheless, the main trajectory of this "crisis literature" attests to the disrupting potency of suffering. In chapters 17 and 21, Job explicitly objects to the notion that temporal prosperity is always the reward of virtue as temporal adversity may not be the punishment of sin. In fact, evil persons are frequently seen to prosper in this life irrespective of the fact that they merit nothing good from God for which they suffer no serious adversities/misfortunes.

A possible objection against the above consideration is: if evil persons can prosper and no serious adversity befalls them, then why should good works matter? Here, it might be appropriate to refer back to Qohelet who says, "The same things happen to everyone, and so the hearts of the sons of men are filled with evil" (9:13). He continues to offer what could be taken as an answer to the objection: "Nevertheless, since their own goods are not in their hands, let their counsel be far from me". In order to understand this point, we need to draw attention to the notion of free will. Certain goods or virtuous works are voluntary, and they are in the hands of persons who are aided by the grace of God. However, even those who think that they possess it cannot possess the goods of temporal prosperity. Virtuous persons can suffer unintended adversities. Sometimes death could be an equaliser of all. In fact, all are equally fated, in this regard. For their bodies are disposed equally after death, and so he says, "And yet they will sleep in the dust in the same way", because they will be buried in the earth equally, "and worms will cover them", for their bodies are destined to the same decay which could even be considered the ultimate absurdity.

Job presents three reasons why God should spare him (cf. ch.7, p 16-21). First, Job says, "What will I do for you, O guardian of men?" to make a point that humans are frail and that they are incapable of making satisfaction or the remission of sins. Second, Job complains saying, "Why do you pit me against you?" to make an appeal based on the powerlessness of humans to persevere themselves without divine grace. Finally, Job's cry "Why do you not take away my sin?" and "Why do you not take away my iniquity?" is expressive of his appeal from the morally compromised nature of the human condition (to cleanse itself from sin and iniquity). Overall, the appeal articulates an antimeritocratic anti-determinism (the determinism of fate/God). In Gustavo Gutierrez's liberationist idiom: "poverty and abandonment are not something [divinely] fated" (1987, p 32).

Of course, the notion of merit-retribution is not compatible with determinism. It is because humans-distinguished from the animal kingdom-possess free will and that the issue of deserved merit or demerit can be considered (Aquinas, 2016 Caput 7). Otherwise, merit-demerit is inapplicable to irrational creatures. In Job, we find an account of theodicy not as an intellectual problem as such, but as a practical one. Theodicy, as a practical problem, expresses the psychological struggle of the person undergoing suffering. When a person asks, "Why did this happen?" she/he implies the futility of their suffering. Job goes on to show, not only the futility of preserving his life but strikingly the harm: "For now I would be sleeping (death) and quiet (rest from adversities); I would be at rest". The whole point is that the preservation of life is not something that should be desired, because both the haves and the have-nots will meet the same end. Death marks the end of merit defined in possession of corporeal goods or temporal prosperity.

Thus far, we noted meritocratic thinking is part of our everyday life. As a regime of subjectivity, it controls many facets of our life in the world. The closeness of meritocracy to societal life is mediated and facilitated by religion. Theological notions of grace, covenant, election and salvation can sanction the notion of merit. This is not to say that salvation is merited in the Christian faith. Historically, the place of merit in the Christian tradition has been debated. However, even as religion can be appropriated to legitimise the merit-retribution logic of economy, it can also serve to critique meritocracy. Not only the interpretation of worldly success as merit, but also the interpretation of failure as retribution are both problematised. A summons for the replacement of epistemic certainty with epistemic humility clearly reverberates in both Qohelet and Job.

The crux of the matter has nothing to do with juxtaposing "protesting wisdom" with "dogmatized wisdom" (as some claim) for both Qohelet and Job do not deny or reject theistic wisdom 
(Fox, 1989, p 145). Instead, they demonstrate the other face of the reality of disruptive exceptions. Arguably, religion plays a significant role-in both the past and present-by offering the "solution" to injustice (economic or other) in the world through a juxtaposition of a just God and an unjust world and the ultimate reconciliation of God and the world. Indeed, associating religion with the legitimisation of meritocracy is an inappropriate positioning of religion, amounting to a kind of functionalist reductionism. The discussion above could lead us to this kind of conclusion. The reduction of religion to a cultural convention becomes clear if we consider empirical examples-not necessarily from a modern capitalistic society but even from a traditional one that thrives to modernise such conventions. In what follows, I wish to expand the horizon of this discourse by drawing on examples from the Ethiopian experience.

\section{The metaphysics of fate and the myth of social mobility: the Ethiopian example}

In the previous section, we have dealt with meritocratic religion/ theology and counter-meritocratic wisdom. In what follows, I wish to broaden the horizon of the previous discussion through a brief elaboration of the metaphysics of fate and the myth of social mobility in Ethiopia. I will then offer a cursory reflection on the historical archives and cultural memories of Ethiopians pertinent to belief in merit. The purpose of this section is to illustrate how and why empirical considerations of religious phenomena, and the manner in which they sanction cultural conventions ${ }^{4}$ and/or counter disruptive convictions, are important for a deeper understanding of inequality and poverty.

\section{Cultural conventions.}

[by] instinct, he [the "typical" Ethiopian] knows what he is, what is the exact measure of the place which he occupies within his family, and at what height is found the level occupied by his family in the social scale. He is convinced that it is the Good God himself who put him where he is and put the others where they are, but he tries to elevate himself all the same by his merit. However, in his respect for those who are placed higher than he, he entertains always a sentiment that is quasi-mystical, and he accommodates himself with good grace and never transgresses. (Cited in Markakis and Ayele, 1978, p 15)

So says Mhteme-Selassie Wolde-Maskal-a member of the ruling class in 1966 before the 1974 Ethiopian revolution. In his remark, Mhteme Selassie assumes merit is a characteristic feature of Ethiopian life, and I follow suit. In the above comment, we recognise at least three important points that can serve as an outline for our subsequent discussion. The first point has to do with cultural authenticity in Ethiopia. The typical Ethiopian is construed as one who possesses an instinctive knowledge of divine placement according to one's merit. The language of hierarchy implied by words such as "exact measure", "scale", "height", "elevate", and "higher" describe Ethiopia as a hierarchic/ stratified or a functionally differentiated society in sociological terms (cf. Levine, [1972] 1965) while it affirms that the belief in merit is a characteristic feature of Ethiopians. Meritocracy is not a characteristic feature of undifferentiated holistic societies. The reference to "instinct" confirms that the cultivation of the self is inseparable from the process of socialisation in which belief in merit is central. Put differently, merit is socially constructed or culturally in-built, and hence, the moral development of Ethiopians (from childhood) is conditioned by this quasireligious phenomenon.
Second, we discover the religious legitimation of merit. Since religion is a defining aspect of the Ethiopian worldview, it is impossible to think of cultural development in Ethiopia without any reference to religious and metaphysical beliefs. It is, then, natural to see the parasitic growth of meritocracy under the auspices of religion. The interplay between merit and religion becomes obvious in the expressions: "... convinced that ... God himself ... put ..." that strongly indicate that belief in merit is embedded in and mediated by religion. Put simply, God and religion are evoked here to sanction merit and demerit, wealth and poverty, rich and poor.

The last point relates to the myth of social mobility. The expression "... [he/the Ethiopian] accommodates himself with good grace and never transgresses" demonstrates the cultural convention of a consensus society. The typical Ethiopian believes that he/she can be elevated (by his/her own merit) and demoted (due to demerit) on the social ladder. Consequently, the typical Ethiopian never attempts to transgress through revolutionary acts. Given the history of revolution in Ethiopia, however, this may be an untenable conclusion. If religion produces docile bodies that cannot transgress (or, resist unjust systems), what do we make of the 1974 revolution?

As we shall see later-through a cursory look at the poetic expressions of ordinary people-such common understandings framed by religion can be disrupted by experience. Before looking at that, however, I wish to elaborate the metaphysical and religious legitimation of merit within the Ethiopian context, to develop further the tentative outline discussed above.

A good starting place for such a study is the work of Donald Levine. Levine attributes idil (fate/fortune) a central place in Ethiopian culture. However, his interpretation is mainly construed in the negative (i.e., fatalism). In contrast, Messay Kebede offers a more positive construal of idil. ${ }^{5}$ For Messay (1999, p 185), $i d i l$ "is at the antipodes of fatalism and resignation, since fate is not so much certitude as a constant quest". In light of such an interpretation, the understanding of idil in terms of docility, hopelessness, and lack of motivation for change has to be rejected. Such an understanding of idil is contrary to fixed merits and demerits for there is always a flexibility implying a reversibility of positions that gives aspiring individuals the possibility of moving up in the social hierarchy.

Idil, Messay argues, is not a purely natural phenomenon; instead, it is connected to the theological notions of covenant and election (akin to Weber's analysis of the Protestant ethic). Consequently, idil turns every acquired thing into God's gift (Kebede, 1999, p 183). According to this conception, "grace creates inequalities"-individuals occupy different hierarchies of positions analogous to Leibniz's hierarchy of monads (Kebede, 1999, p 214). For Messay, semna worq (literally translated as wax and gold; the former implying literal meaning while the latter refers to the hidden/true meaning), and similar indigenous poetic expressions exhibit not only a literary style but also a metaphysics embedded in Ethiopian religiosity. The metaphysics of wax and gold distinguishes between appearance and essence-the former having the potential to veil the latter-a conception reminiscent of Platonism. The movement from the wax to the gold is like ascent to a higher, truer, and absolute reality, the implications of which are not only restricted to epistemology but also extend to social ontology.

Ascent to, as well as descent from, a status-including economic merits-are seen in light of the metaphysics of wax and gold, expressed in a topographic metaphor of lower and higher positions as we have observed in Mhteme-Selassie's remarks. However, although the positions are fixed by fate (or fated), the hierarchy is flexible allowing people to move along it. This constitutes the Ethiopian myth of social mobility, which 
operates in upward and downward directions. For Messay, the reversibility of positions appears to have affinity with the Heracletian view of the reversal of superiors and subordinates: "war is the father of all and king of all ... some he makes slaves, others free" (as cited in Kebede, 1999, p 186). Of course, such associations are unfortunate because the Heracletian chaos sacralises conflict and (presupposes an original/ontological) violence (cf. Milbank, 2009, p 279; 2006, p 5). On this conception, violence is determinative in the fate of individuals in either higher or lower positions. Binding together those fated for higher and those destined for lower positions is the concept of time (gize), understood not as a linear progression but as reversal (Kebede, 1999, p 192-193), which has affinities with the Bergesonian understanding of time as reversal. Here, what effects the reversal cannot be free of violence.

Now, prior to commenting on Messay's analysis of the traditional matrix, allow me to make a brief detour in order to look at how the contemporary religious expressions in Africa fit into this scheme. Of course, there is obviously a direct relationship between African Christianity/spirituality and economic life in general. This could be noted from Paul Gifford's remark (1998, p 346): "Their results-oriented and pragmatic spiritual life spills over to make their work life results-oriented and pragmatic too". Gifford's analysis is narrowly focused on the business-like church and para-church industries in Africa that began to flourish since the 1970s. In today's Africa, as elsewhere in the world, the socalled "prosperity gospel" preached by some Charismatic and Pentecostal groups has made wealth and its acquisition central to religious belief and practice. According to such expressions of religion, the flow of wealth/money/statuses do not belong to the domain of the natural only. Their operations are considered more than a natural phenomenon, akin to what Messay argues about the notion of idil. Here, the domain of the supernatural or the miraculous- "that is, the belief that anything is possible" (Mbembe, 2002, p 270)—permeates the imagination of religious believers.

Consequently, one seeks to overcome material obstacles by the power of the supernatural for the miraculous is believed to change the rhythm of material life. In this process, we notice the centrality of charisma, which exhibits paradoxical features. On the one hand, charisma is possessed only by a few chosen (by God) and "anointed" (by the Holy Spirit) in order to minister or offer services to communities while, paradoxically, everyone could access it to partake in grace. Aspiring individuals who wish to ascend on the social ladder are then admonished to do this not by their own capabilities but by the help of charisma. If the aspiring individual believer succeeds, credit is given to God and this may include sharing benefits to the possessor of the charisma through whom God released his grace. In absence of success, the charismatic leader may diagnose a generational curse that hinders the aspiring believer from material blessings and promotions. In this case, spiritual rituals (e.g., prayer, fasting, giving offerings and tithes) are performed to break the curse and change the fate of the individual. In general, what the contemporary religious expressions affirm demonstrate an affinity with Messay Kebde's analysis of the traditional matrix.

Now allow me to forward some critical remarks on Messay Kebede's analysis of the traditional matrix. Taking the traditional matrix as a normative ideal for society could be detrimental in some ways: first, there is an obvious legitimisation of inequalities even when they result in demeaning poverty. This can be tantamount to rationalising poverty. Society, then, develops moral numbness towards the poor without feeling guilty or responsible in any direct way. Of course, this is not to deny the existence of practices of mercy and charitable giving. Second, the emphasis on belief in merit and the myth of social mobility-although they may offer society with a serviceable social imaginary that could add a propensity for economic growth/development-inevitably leads to competitive egoistic individualism whereby only the fittest survives, which has less regard to the bonds of togetherness and mutual responsibility. The rule is "from where you are you cannot improve your lot; so you must ascend to a higher position. And such places being limited, someone else must be dislodged and degraded" (Kebede, 1999, p 220)-a conception that never encourages horizontal solidarity. Third, the notion of merit (idil) is being used as a cover-up fig leaf to make social determinism look less evil. Finally, the account of the religious sanctioning of meritocracy empties religion (particularly Christianity) of its critical capacity. It gives the impression that religion could only conform to cultural conventions without causing any disruptions to the status quo. The discussion that follows addresses this last problem by rehearsing what ordinary subjects express themselves in a subversive manner.

Disruptive convictions. Much of the scholarly discussion reiterates the assumption that "heavy fatalism" characterises Ethiopian life, and that demerit, poverty, famine, and disaster are considered as "ordained by fate" (Clapham, 1969, p 6; Rahmato, 1990, p 39). In a similar vein, the Ethiopian scholar Mesfin Woldemariam argues,

In the context of Ethiopian culture, famine is not a natural calamity, $[. .$.$] no human being or human institution can be$ held responsible for it [...] famine has proved to be a convenient and successful means of disclaiming its responsibility and obligation to avert famine. The same perception has enabled the people to accept suffering and death with peace and equanimity. (1984: 141-3)

Against this tide of scholarship, Messay Kebede argues that such an interpretation is the result of confusing fatalism with religious clientelism. Although, undeniably, there is an attribution of famine to sin (of satiety, for example) and God's retribution, as affirmed by the historian Richard Pankhurst (1986, pp 10, 17), fatalism on its own cannot give a complete picture. Messay's argument is that Ethiopians do not passively accept their "fate" (as if fixed and unchanging) but do their best to re/align themselves to God through a prayer of confession (egzio meharene KristosO Christ forgive us) so as to curb the consequences of famine and disaster. I agree with Messay Kebede to the extent that people do not accept "suffering and death with peace and equanimity" (as Mesfin Woldemariam claims). One poignant example of responses to suffering in Ethiopia, the poetic expressions of ordinary people in response to famine does much to refute this claim. For this task, I wish to reflect on some couplets taken from Fekade Azeze's work (1998, p 138):

I will sue him in court,

I won't leave him lightly; I won't;

While he exterminates, from the surface of the earth,

\section{The values and dignity of man!}

This couplet is an example of how suffering people question the justice of God, thereby, demonstrating the absence of docile fatalism. This is not the voice of people who suffer from heavy fatalism. In the face of people perishing because of hunger and starvation, religious people question the existence of a good, omnibenevolent God. Of course, this does not mean that people abandon their faith because of the practical theodicy they encounter. Nonetheless, they complain and protest against God 
for allowing such a calamity happen. In another couplet (Fekade Azeze, 1998, p 105), we look at the depiction that God is a just judge when he allows such calamities:

Surely, God cannot be suspected on one regard,

He will not kill the poor, and leave the rich behind.

This poem expresses that people consider death as the equaliser of all-befalling on the poor and the rich without any discrimination. Nevertheless, although God seems to be praised for his indiscriminate judgement, his justice is ironically questioned. God allows and tolerates unjust inequalities, and his judgement is protracted and kept until the advent of famine. Moreover, the only instrument God deploys appears to be mass extermination through disaster and famine.

In light of these poems, Mesfin Woldemariam's reference to dying with peace and equanimity is not an accurate representation of the Ethiopian reality, although his point about the abnegation of responsibility by governments may be separately evaluated on its merits.

Poems against political leaders abound in literature containing poetic expressions of ordinary citizens. For example, the following couplets (Fekade Azeze, 1998, pp 117-118, 204) appear to be critical of the previous communist regime-especially, the antireligious stance of the party members and their endless meetings to indoctrinate and control people, and the lack of good governance due to unfitting governors appointed through party affiliation (political meritocracy):

Clouds faded from the sky,

Rain vanished from the earth,

As if angered by the braying of committees.

It is the government that did us the most wrong.

Scattering Appointments right and left,

Making everyone a chief!

Now what use is such a number of bosses?

Cases are not dealt with in depth,

So justice is never carried out.

Our look at merit within the particular context of Ethiopia serves to demonstrate an interesting framework combining the concept of idil (fate) with that of gize (time). We noted that according to this perspective both ordained social location and social mobility are theoretically possible. Through the examples we looked at we were also able to note how people can respond to suffering with protest wisdom that may seem to counter their overarching religious and metaphysical worldview.

\section{Final considerations}

In the foregoing discussion, we have drawn on theoretical and empirical works to look at how religion could legitimise and critique meritocracy. While meritocracy demonstrates a capacity to discipline the whole of life, as a regime of subjectivity, religion can always create a critical distance to resist it. There are theological resources that can be generated from religious texts and protest wisdom countering meritocratic ideology. Why does the foregoing discussion matter and where does it lead? Allow me here to conclude the discussion by suggesting three moral considerations or protocols on meritocracy vis-à-vis inequality and poverty, which will contribute towards correcting flawed conceptions of economic poverty and development.

From merit to mercy. The opposite of merit is not demerit. Demerit is just another side of merit. Rather, mercy is the opposite of merit. The interpertation of grace as a sign of material success (money) is reductive of religion and its values. If grace is interpreted as money, then, money can also be interpreted as grace. Those who are successful in terms of merit/money are also considered as already possessing grace and are not required to convert or confess. Material wealth becomes the same thing as spiritual wealth. In this context, grace creates inequalities. In viewing meritocracy as a regime of subjectivity, we need to consider the critical distance religion should maintain.

Meritocracy defines the world in terms of competitiveness, not cooperativeness: merit implies scarcity, which could be factual or imagined. As we noted above, for one to make it up on the social ladder, another must be dislodged and degraded. In a milieu of scarcity, as Jean-Paul Sartre claims, our common living is endangered by an unhealthy competitiveness: "In pure reciprocity, that which is Other than me is also the same. But in reciprocity as modified by scarcity, the same appears to us as antihuman in so far as this same man appears as radically Otherthat is to say, as threatening us with death" (Sartre, [1960] 2004, pp xviii-xix, 131-132). This leads to a construal of life as the survival of the fittest whereby those with merit survive while the disadvantaged are subjected to what Marx and Engels (1999, p 84) referred to as "the violence of things"- not a spectacular violence-but a silent form of dehumanising violence that results from the denial of things necessary for the survival of the worstoff. Unemployment, poverty and destitution are the objective and material manifestations of the violence of things. Under economic conditions that make scarcity normative (Robbins, 1932, p 16), and meritocracy the ideal, this violence can easily pass as an "oversight" - understood not as failure of sight but a rationalised and intentional refusal of sight (echoing Althusser and Balibar, $1979, \mathrm{p} 21$ ). This is a devaluation of human dignity and an empoverishment of virtue, which grace and mercy foster.

Institutions of mercy. The whole exercise of economic rationalisation based on the notion of desert, in the final analysis, leads to the rationalisation of demerit/retribution. Such rationalisation eventually leads to a moral scarcity of sympathy and spiritual/ affective numbness towards the poor. Aleatoric meritocracywith its pretensious issuance of the equality of opportunity-has a way of looking at some unexpected results as anomalies, not as limitations of its internal rationality. To the benefit of the worstoff and the ethic of cooperative togetherness, there should be an "epistemic mercy" that leads to the recognition of: "the particular" (as opposed to "the general" of economic calculations), the need "to live with the contradictions and the challenges of the tragic," the limits of our knowledge and economic/development calculations (Sedmak, 2007, p 146-147). The proposal, here, is that since mercy is the opposite of merit, the effects of the merit/desert logic should be curbed by mercy. In a world of competition, cooperation should thrive. Creating insitutions of mercy that focus on health care, education, and employment is necessary to foster moral-social transformation. Getting equal access to health care differs from setting up free or less expensive health, but poor health services, to the poor while the better-offs get access to quality services. The same is true to the educational sector. The State should take greater responsibilty in offering people employments (cf. Schweiger, 2014, p 37-61). 
Mercy and the human subject of development. Epistemic mercy requires that we affirm and be humane to the human face of tragic economic contexts. Development practices that aim at curbing poverty are often pre-ocuppied by the rational calculations and manipulation of figures but at the end of the day what matters should be human subjects. What is the development question but a question about the human subjects of development (whose agency need to be affirmed)? Since development agencies themselves-faith-based or otherwise-could be instrumentally used by meritocratic hegemony/ideology serving the meritmachine, there ought to be critical awareness of the dangers of the identikit top-down approach in development that disregards the human subjects of development (Escobar, 1995, p 44).

Received: 29 September 2017 Accepted: 12 December 2017 Published online: 09 January 2018

\section{Notes}

1 Although the relationship between merit and desert is contentious, some scholars oppose the replacement of desert with rights by egalitarian-minded scholars. For further discussions cf. Louis Pojman $(1997,2006)$.

2 Much can be drawn from the Christian tradition, but it is beyond the scope of this paper. To highlight some examples: the development of early Judaism can be interpreted as a critique of Ancient Near Eastern traditions-Mesopotamian religions of sacrifice that fostered a transactional view of sacrifices in which the agent of sacrifice receives merit (Bruni, 2017). The discouragement of merit in the New Testament by Jesus may be similarly understood. Nonetheless, the aversion of merit-based religion is always under critique, as demonstrated in St Paul's critique of the transactional logic in legalistic forms of Judaism (e.g., Rom.4:4-6; Gal.5:5). The notion of merit is antithetical to the Gospel-the latter totally excludes the former because no one is unworthy of the Gospel of Christ (ed. Kittel, 1964, p 379-380). The debate between St Augustine (doctor gratiae, "doctor of grace") and Pelagius, for example, reveals the tension between "salvation by merit" and "salvation by grace" (sola gratia) (McGrath, 1998, pp 35-37, 79-85). Similarly, the critique of Luther against the Catholic Church has to do with the understanding of sola gratia. From an economic-historical perspective, Luther's critique of the Catholic Church and the luxurious ways of life in Italy could be a point of interest (cf. Bruni et al., 2016).

3 Especially, in the gospel of Matthew, we find explicit references to salvation by grace (unmerited) (see Matt. 20:1-16, 21-23; 13) and texts (such as Matt. 6:12, 14-15; $18: 15-35)$ that give the impression that salvation is conditional on forgiveness (merited). Such paradox is not actually unique to Matthew as other biblical books contain a similar tension. Eduard Schweizer (1975, p 155) and others (Tushima, 2011, p 1-11) have, for example, noted the tension between these groups/sets of texts by drawing attention to Matthew 20:1-16 about the parable of the workers receiving equal pay for unequal work.

4 The significant role played by socio-cultural conventions figures in David Hume's antirationalist resonance and non-egalitarian approach: "It is necessary, therefore, to know our rank and station in the world, whether it be fixed by our birth, fortune, employments, talents, or reputation" (Hume, 1911, pp 293, 484-501). The Ethiopian case shows some degree of affinity with Hume's understanding of convention insofar as it gives consensus (based on merit and non-merit factors) normativity. Hume encourages people not to seek a better position but remain where they are in order to develop their skills and natural abilities, which would later bring them more esteem for their excellence. The principle he advances is the importance of living up to the standards required by one's position. Of course, he contends that wealth should not necessarily be the driving motive. The most important point, here, is that conventions are important to coordinate our actions-enabling us to act in predictable ways allowing a distinction between "mine" and "thine" and serving as the "origin" of justice (Gaus, p 225; Hume, 1911 p 484-501).

5 Here, the help of a dictionary is of no avail because the issue at stake is more than semantics. Indeed, the work of Levine shows its associations with fate and fatalism, but Messay has rigorously demonstrated the link between the notion of $i d i l$ and merit and the myth of social mobility.

\section{References}

Althusser L (2008) On ideology. Verso, London

Althusser L, Balibar É (1979) Reading capital. Verso, London

Aquinas T (2016) Expositio super iob ad litteram. English edition: Kenny J Commentary on the book of job. (trans: Mulladay B). Aquinas Institute, Lander, Wyo
Azeze F (1998) Unheared voices: drought, famine and God in Ethiopian oral poetry. Addis Ababa University Press, Addis Ababa

Benjamin W (1921) Capitalism and religion. In: Liedemann R, Hermann (eds) Gesammelte Schriften. Suhrkamp Verlag Schweppenhauser, Frankfurt, 1986

Bruni L (2017) The sad empires of merit. http://www.edc-online.org/.../12868-thesad-empires-of-merit.html

Bruni L, Oslington P, Zamagni S (2016) Economics and theology special issue: Introduction. Int Rev Econ 63(1):1-5

Bulgakov S (2000) Philosophy of Economy: The World as Household (trans. and ed: Evtuhov C). Yale University, New Haven

Clapham C (1969) Haile Selassie's government. Longmans, London

Escobar A (1995) Encountering development: the making and unmaking of the third World. Princeton University Press, Princeton

Fiala A (2015) The Bloomsbury companion to political philosophy. Bloomsbury, London, UK \& New York, USA

Foerster (1964) axios, anaxios. In: Kittel G (ed) Theological dictionary of the new testament, vol 1. Eerdmans, Grand Rapids, MI, p 379-380

Fox MV (1989) Qohelet and his contradictions. Almond Press, Sheffield

Gaus G, D'Agostino F (eds) (2013) The routledge companion to social and political philosophy. Routledge, Oxford

Gaus GF (2000) Political concepts and political theories. Westview Press, Colorado \& Oxford

Gifford P (1998) African christianity: its public role. Indiana University Press, Bloomington \& Indianapolis

Gutiérrez G (1987) On job: God talk and the suffering of the innocent (trans: O'Connell M). Orbis Books, Maryknoll, New York

Hume D (1911) A treatise of human nature, vol 2 (Introd.: A D Lindsay). J. M. Dent \& Sons Limited, London

Hughes J (2007) The end of work: theological critique of capitalism. Blackwell, Oxford

Kebede M (1999) Survival and modernization: Ethiopia's enigmatic present: a philosophical discourse. The Red Sea Press, Lawrenceville, NJ

Koosed JL (2006) (Per)Mutations of Qohelet: reading the body in the book. T \& T Clark, London and New York

Levine DN (1965) Wax and gold. The University of Chicago Press, Chicago and London, 1972: Fifth Impression

Luther HM, Huck G, Patrick HH (1988) Technologies of the Self: A Seminar with Michel Foucault. Tavistock, London

MacIntyre A (1988) After virtue: A study in moral theory, 3rd edn. The University of Notre Dame Press, Indiana

Markakis J, Ayele N (1978) Class and revolution in Ethiopia. Spokesman Books for the "Review of African political economy", Nottingham

Markus H (1975) The life and times of Menelik II: Ethiopia 1844-1913. Clarendon Press, Oxford

Marx K, Engels F (1999) The German ideology. International Publishers, New York

Mbembe A (2002) African modes of self-writing. Pub Cult 14(1):239-273

McGrath A (1998) Historical theology. Blackwell, Malden, MA

McNamee S, Miller RK (2004) The meritocracy myth. Rowman \& Littlefield, Lanham, MD

Milbank J (2006) Theology and social theory: beyond secular reason, 2nd edn. Blackwell, Oxford

Milbank J (2009) Multiculturalism in Britain and the political identity of Europe. Int J Study Christ Church 9(4):268-281

Miller D (1976) Social justice. Claredon Press, Oxford

Pankhurst R (1986) The History of Famine and Epidemics in Ethiopia prior to the Twentieth Century. RRC, Addis Ababa

Pankhurst R (1996) The history of famine and epidemics in Ethiopia prior to the twentieth century. H \& L Communications, London

Pojman L (1997) Equality and desert. Philosophy 72(282):549-570

Pojman L (2006) Justice. Pearson, Upper Saddle River, NJ

Rahmato D (1990) Famine in peasant consciousness: aspects of symbolic culture in rural Ethiopia. In: Bahru Zewde et al. (eds) Proceedings of the fifth seminar of the Department of History, Addis Ababa University, Addis Ababa, p 31-48

Rawls J (1971) A theory of justice. Oxford University Press, Oxford, 1999: Revised edition

Robbins L (1932) An essay on the nature and significance of economic science. Macmillan, London

Sartre J-P ([1960] 2004) Critique of dialectical reason, vol.1. Theory of practical ensembles (trans: Sheridan-Smith A). Verso, London and New York

Schweiger G (2014) Unemployment, recognition and meritocracy. Las Torres De Lucca 4:37-61. (enero-junio)

Schweizer E (1975) The good news according to Matthew (trans: Green David E). John Knox Press, Atlanta.

Sedmak C (2007) The wound of knowledge: epistemic mercy and world hunger. In: Davies O, Janz PD, Sedmak C (eds) Transformation theology: Church in the World 2007. T \& T Clark, London and New York, p 142-166

Tanner K (2005) Economy of grace. Fortress Press, Minneapolis 
Taylor C (2004) Modern social imaginaries. Duke University Press, Durham and London

Taylor C (2007) A secular age. The Belknap Press of Harvard University Press, Cambridge, MA and London

Tushima C (2011) The paradox of the new testament concept of unmerited divine grace and conditional forgiveness in Matthew's Gospel. Afr J Evang Theol 30 (1):1-11

Weber M (1976) The Protestant ethic and the spirit of capitalism (trans: Parsons T). Allen and Unwin, London

Weber M ([1930] 2005) The Protestant Ethic and Spirit of Capitalism. Routledge, London

Woldemariam M (1972) An introductory of geography of Ethiopia. Berhanena Selam H.S.I. Printing Press, Addis Ababa

Williams R (1999) Sergii Bulgakov: towards a Russian political theology. T \& T Clark, Edinburgh

\section{Data availability}

Data sharing is not applicable to this article as no datasets were generated or analysed during the current study.

\section{Acknowledgements}

The author thanks Mark Elliot, Andrew DeCort and Meron Tekleberhan for their comments and feedback on this paper. He also expresses his gratitude to Luigino Bruni for his inspiring keynote lecture, "Human Flourishing and Free Market Economy: On Meritocracy and Incentives" presented at the Christianity and the Future of Our Societies conference in Leuven $(E T F)$ in 2016, to which the author was given the honor of presenting a response.

\section{Additional information}

Competing interests

The author declares that there are no competing financial interests.

Reprints and permission information is available online at http://www.nature.com/ reprints

Publisher's note: Springer Nature remains neutral with regard to jurisdictional claims in published maps and institutional affiliations.

\section{(c) (i)}

Open Access This article is licensed under a Creative Commons Attribution 4.0 International License, which permits use, sharing, adaptation, distribution and reproduction in any medium or format, as long as you give appropriate credit to the original author(s) and the source, provide a link to the Creative Commons license, and indicate if changes were made. The images or other third party material in this article are included in the article's Creative Commons license, unless indicated otherwise in a credit line to the material. If material is not included in the article's Creative Commons license and your intended use is not permitted by statutory regulation or exceeds the permitted use, you will need to obtain permission directly from the copyright holder. To view a copy of this license, visit http://creativecommons.org/ licenses/by/4.0/.

(C) The Author(s) 2018 